\title{
Effect of Profitability Financial, Ratios Return on Assets, Return on Equity, Gross Profit Margin and Inflation Level of Stock Return Manufacturing Company Recorded Activities in LQ 45
}

\author{
${ }^{1}$ Dwi Sihono Raharjo and ${ }^{2}$ Riska Widarti \\ ${ }^{1,2}$ Faculty of Economics and Business, Universitas Persada Indonesia-YAI \\ Jakarta, Indonesia \\ e-mail: dwisihono.raharjo@gmail.com
}

\begin{abstract}
This study aims to analyze the effect of financial performance on stock returns on manufacturing companies listed on the Indonesia Stock Exchange in the period of 2013 until 2017. The independent variable used in this study is financial performance. The financial performance referred to here is the financial performance measured by using the Return On Assets (ROA), Return On Equity (ROE), Gross Profit Margin (GPM), and Inflation Rate while the dependent variable is Stock Return. The sample in this study consisted of 13 manufacturing companies in the consumer goods sector which were listed on the Indonesia Stock Exchange (IDX) in the 2013 study period to 2017 is chosen based on certain criteria by using purposive sampling method. Analysis of the data used in this study is multiple linear regression analysis ( $\mathrm{t}$ test and $\mathrm{f}$ test) which is processed with Eviews 9. From the multiple regression model used in this study, the results of partial testing ( $t$ test) showed that only three variables namely ROE, GPM and Inflation Rate had a significant positive effect on stock returns, while ROA had no significant effect on stock returns. While simultaneously (test f) shows that ROA, ROE, GPM, and the level of inflation together affect the stock return.
\end{abstract}

Keywords: Financial performance, Return On Assets (ROA), Return On Equity (ROE) and Gross Profit Margin (GPM), Inflation Rate, Stock Return

DOI: $10.7176 /$ RJFA/12-24-05

Publication date: December $31^{\text {st }} 2021$

\section{INTRODUCTION}

Financial statements are prepared with a view to presenting the company's progress report periodically. Financial statement information has a specific purpose, namely providing information on economic resources, liabilities and capital shares, providing comprehensive income information and providing cash flow information. Financial statements are expected to provide information relating to the company's level of profit, risk, financial flexibility, and operational capabilities.

Investors invest money in the hope of getting a return on the investment in addition to keeping the investment from decreasing in value. Decision makers including investors in investing their funds require a variety of useful information to predict the results of their investments in the capital market. Information commonly used by investors or financiers is grouped in two things, namely information of a technical nature and fundamental information (Claude et al. , 1996). Jogiyanto (1998) states that the information needed by investors in the capital market is not only information that is fundamental, but also information that is technical. Information that is fundamental is obtained from the company's internal conditions and information of a technical nature is obtained from outside the company, such as economics and politics. Information obtained from the company's internal condition that is commonly used is financial statements. Fundamental information is information related to the condition of the company that is generally indicated in financial statements which is one measure of the company's performance. The fundamental information of a company commonly used to predict stock prices is a variety of measures of a company's performance shown in financial statements. Based on financial statements can be known several fundamental factors, among others: financial ratios, cash flow and measures of performance associated with Stock Return.

According to Robert (1997), financial ratios are grouped into five types based on scope or goals to be achieved, namely liquidity ratio, solvency ratio (leverage), profitability ratio, activity ratio, and market ratios. Financial ratios commonly presented on the Jakarta Stock Exchange (JSX) Statistics include profitability ratios, solvency ratios and market ratios to internal (quarterly) report periods and annual reports.

The extent to which a company can affect the price of shares in the capital market so as to provide returns to owners of capital and what variables can be used as indicators for the company to control the price of shares. So that the company's goal to increase the value of the company through increasing the value of shares traded in the capital market can be achieved.

ROA is a comparison between net sales before interest and taxes on total assets. According to Laurent Novelia's research (2012) there is partially a significant influence of ROA on Stock Returns. Meanwhile, according 
to the research of Maya Dini and Nurhayati (2015) partially there is no significant influence between ROA and Return Shares.

Researchers Fernandez (Pradhono and Christiawan, 2004) compared the correlation between ROE and returns received by shareholders. The results showed that interest rates with returns have a high correlation. Nuryana (2013), partially GPM does not have a significant influence on stock return. These results contradict the results of Sparta (2000) and Indradewi (2004) studies which showed that GPM had no significant effect on stock return, so further research was needed.

Baramuli (2012), partially inflation has no significant effect on stock returns. Meanwhile, according to Dwira and Rahmidani, partially inflation has a significant negative effect on stock returns. Based on the differences in the results of the above research, the formulation of the problem in this study is that there are still differences in research about factors that affect stock returns. Research is needed to link the company's performance as measured by the financial ratios of profitability (ROA, ROE, GPM) and the rate of inflation to Return Shares in manufacturing companies listed actively in LQ 45 on the Indonesia Stock Exchange in the period 2013-2017.

Based on this description, the question of this tian peneliis as follows:

1. Is there a partial effect of the financial ratio of Return on Assets (ROA) to the Return shares of manufacturing companies listed actively in LQ 45 on the Indonesia Stock Exchange for the period 2013 to 2017?

2. Is there a partial effect of the financial ratio of Return on Equity (ROE) profitability to return shares of manufacturing companies listed actively in LQ 45 on the Indonesia Stock Exchange for the period 2013 to 2017 ?

3. Is there a partial effect of gross profit margin (GPM) financial ratio on return shares of manufacturing companies listed actively in LQ 45 on the Indonesia Stock Exchange from 2013 to 2017 ?

4. Is there a partial effect on the return of shares of manufacturing companies listed actively in LQ 45 on the Indonesia Stock Exchange from 2013 to 2017?

5. Is there an effect on the financial ratio of ROA profitability, ROE, GPM and Inflation Rate simultaneously on return shares of manufacturing companies listed actively in LQ 45 on the Indonesia Stock Exchange for the period 2013 to 2017 ?

In accordance with the proposed problem, the purposeof this research is to:

1. Analyzed the effect of the financial ratio of return on assets (ROA) partially to the return of shares of manufacturing companies listed actively in LQ 45 on the Indonesia Stock Exchange from 2013 to 2017.

2. Analyzed the effect of the financial ratio of Return on Asset (ROE) profitability partially to the Return shares of manufacturing companies listed actively in LQ 45 on the Indonesia Stock Exchange for the period 2013 to 2017.

3. Analyzed the effect of gross profit margin (GPM) financial ratio partially on return shares of manufacturing companies listed actively in LQ 45 on the Indonesia Stock Exchange from 2013 to 2017.

4. Analyzed the effect of the Inflation Rate partially on the Return of shares of manufacturing companies listed actively in LQ 45 on the Indonesia Stock Exchange for the period 2013 to 2017.

5. Analyzed the effect of the financial ratio of Profitability ROA, ROE, GPM and Inflation Rate simultaneously on return shares of manufacturing companies listed actively in LQ 45 on the Indonesia Stock Exchange period 2013 to 2017.

\section{THEORETICAL REVIEW}

\section{Ratio Analysis}

Ratio describes a relationship or balance (mathematical relationship) between a certain amount and another amount, and by using analytical tools in the form of this ratio will be able to explain or give an idea to the analyst about the good or bad state ofthe status of the financial position of acompany, especially if the ratio number is compared to the ratio number used asa standard (Munawir, 2004).

By using ratio analysis is expected to be able to determine the level of liquidity, solvency and effectiveness of operations and the degree of profitability of a company (profitability of acompany). To be able to determine or measure these things requires a comparison tool and ratio in the industry as a whole of the same kind of where the company becomes a member that can be used as a comparison tool from the ratio of a company, the ratio of the industry as a whole is called standard ratio (Munawir, 2004).

\section{Profitability Ratio}

Profitability ratio or also called rentability describes the company's ability to earn profits through all existing capabilities and sources such as sales activities, cash, capital, number of employees, number of branches and so on. The use of profitability ratio can be done using comparisons between various components in the financial report, especially balance sheet statements and income / loss statements. Measurements can be made for several 
periods of operation. The goal is to see the development of the company in a certain time span, either decrease or increase, while looking for the cause of the change.

\section{a) Return on Assets (ROA)}

ROA (Rerturn on Assets) can be interpreted as the result of a set of corporate policies (strategies) and the influence of environmental factors. The analysis is focused on the profitability of an asset, and thus does not take into account ways to fund the asset. ROA analysis measures a company's ability to generate profits using total assets, after capital costs have been incurred from the analysis. The focus of ROA analysis is profitability, independent ofits capital (Mamduh, 2007). ROA is used to measure the effectiveness of companies in making profits by utilizing assetsowned. According to (Riyanto, 2013)This ratio is the most important ratio among existing rentability ratios.

\section{b) Return on Equity (ROE)}

Investors certainly want to know the rate of return of the invested funds. The ratio used to determine the return of invested capital is the ROE (Return on Equity) ratio. ROE is part of the profitability ratio, which is a ratio that assesses a company's ability to make a profit. This ratio also provides a measure of the level of effectiveness of a company's management. It is directed by the profits generated from sales and investment income. The point is that the use of this ratio to indicate the efficiency of the company.

Roe ratio is very important for investors in investing. Investors will compare the ROE ratio of a company with other similar companies or compare the ROE of a company with the ROE of JCI. Investors will choose companies that have a high ROE rate because the greater the value of ROE, the more efficient the use of their own capital in generating after-tax profits so that investors get a high Return on Shares.

\section{c) Gross Profit Margin (GPM)}

The main purpose of the company is to earn profits. The higher the company's profit, the better it performs. One indicator of a company's success is its high level of profitability. The profitability ratio examined in this study was the GPM (Gross Profit Margin) ratio.

\section{Inflation Rate}

Inflation rate is the process of decreasing the value of currencies continuously (continue) and affect each other. Price increases that can be influenced by increased demand for goods and services, causing increased demand for factors of production. Increased demand for factors of production leads to an increase in the price of factors of production. So inflation can be generated by an excess of total demand that leads to price increases. Or in other words the cause of inflation due to pressure from the supply side, from the demand side, and from the expectations (expectations) of inflation. Inflation by Samuelson and Nordhaus in Lomi (2012) was summed up as an increase in the general price level. The results of Mankiw's research (Kuswarha, 2013) state that inflation occurs due to a general and continuous increase in prices. Another expert opinion also reveals that Inflation is defined as a symptom where the general price level increases continuously (Kewal, 2012).

According to the same expert there are three components that mustbe fulfilled in order to be said to be a condition of inflation. These components are as follows:

1. There is a tendency for prices to increase. This tendency can mean that it could be the price level that occurs at a certain time. down or up compared to the previous price, but still shows an increasing trend.

2. The price increase occurs continuously. This indicates that the price increase does not occur at one time only, but in a certain period of time (pangjang period).

3. The price level in question is the price level in general. Thus, the price level in question is not just the price level or some conditions only.

Inflation rate arises due to pressure from the supply side (cost push inflation), from the demand pull inflation, andexpectations (expectation inflation). Factors for cost push inflation can be caused by exchange rate depreciation, the impact of foreign inflation, especially trading partner countries, increases in commodity prices regulated by the government and negative supply shock due to natural disasters and disruption of distribution.

\section{Effect of Independent Variables on Dependents \\ 1. Effect of ROA on Stock Return}

ROA is the ratio between net income after tax (Intention) to total assets. The higher the ROA indicates the better the performance of a company, so the company's stock price also increases. The increasing ROA shows the company's improved performance and shareholders will benefit from the dividends received.

With the increasing dividends that will be received by shareholders is an attraction for investors and or 
potential investors to invest in the company. With the attraction brings an impact on prospective investors to own more and more company shares. If the demand for company shares is more and more then the price of the company's shares in the capital market tends to increase. With the increase in the price of the stock, the capital gain of the stock also increases. This is because the actual return is the difference between the current period's Stock price and the previous Stock price (Robert, 1997).

According to Wahyuni (2013) which states that there is no roa effect on stock return as it has been explained that this ratio is used to measure management's ability to obtain clean profits and use of assets. There is no significant effect of ROA variables on Stock Returns. This means management cannot use total assets properly (current assets and fixed assets) and ultimately cannot increase the company's Stock Return.

H1: Roa ratio is influential and significant to Stock Return

\section{Effect of ROE on Stock Return}

ROE ratio to measure capital's own ability to generate profit after tax. This ratio measures how much profit a company makes compared to the paid-up capital of shareholders. The greater the value of ROE, the more efficient the use of capital itself in generating profit after tax. Companies with high ROE can increase investor confidence to invest in the company continuously because the profits that will be obtained are large and vice versa if roe is low then investment interest will fall so that it can lower the company's stock price which means that the Return of Shares will fall.

There are several studies that examine the effect of ROE on Stock Return, but the results of these studies vary. Research Rosa, M., \& Mulyani, E. (2013), states that there is a positive and significant influence between ROE on Stock Return while research Sudiyanto and Suharmanto (2011) states that there is a significant negative influence between the ratio of ROE to Return Shares.

H2: Ratio of Influential and significant ROE to Stock Return

\section{Effect of GPM on Stock Return}

GPM is one of the profitability ratios. This ratio reflects or describes the gross profit that can be achieved every rupiah of sales or if this ratio is reduced to $100 \%$ it will show the amount remaining to cover operating expenses andnet income (Munawir, 2013). The function of GPM is to measure how much gross profit the company earns from sales activities. With a large gross profit, the greater the company's ability to pay operational costs and tax expenses that must be paid by the company.

According to research Engrossed (2011), GPM has a positive and significant effect on Stock Return according to Nuryana research (2013) states that GPM has no significant effect on Stock Return.

H3 : Influential and significant GPM ratio to Stock Return

\section{Effect of Inflation Rate on Stock Return}

The inflation rate has a direct negative influence on the return means that the higher the inflation, the lower the return of shares obtained by the company, it can be interpreted that the increase in inflation has an impact on society prefers to meet the needs and spend the money on needs in accordance with interests only without wanting to borrow money to the bank because inflation is not accompanied by income.

The effect of the inflation rate on Stock Returns is supported by research vidyarini Dwita and Rose (2012) which states that inflation has a negative and significant effect on stock returns while according toresearch Sambelay, J. J., Van Rate, P., \& Baramuli, D. N. (2017) states that inflation has no significant effect on stock return.

H4: Inflation Rate has an effect and significant impact on Stock Returns 


\section{Conceptual Framework}

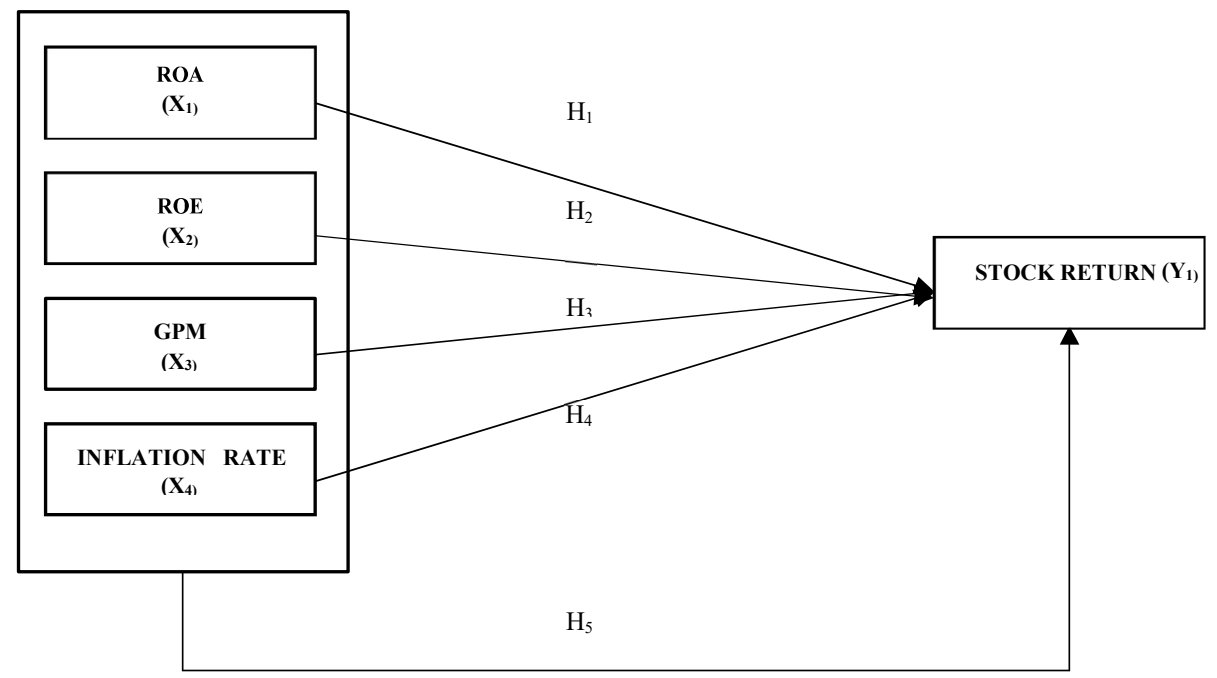

Figure 1. Theoretical framework of thought on ROA, ROE

Source: Data processed by researchers

\section{METHOD}

This research is quantitatively descriptive. In this study will be described the relationship of ROA, ROE, GPM and Inflation Rate to Return Shares of manufacturing companies listed on the IDX. The data used in this study is secondary data, where this secondary data is the main data used as a research database and the data needed to strengthen the analysis. The object of the research used is a company listed in the IDX where information is widely available. In addition, data is also collected from printed books, research journals, theses, websites, and pages of manufacturing companies.

This type of research, using this type of Hypothesis Research with a cross section and time series approach. Cross Section is the study of measurements or observations simultaneously at a time, while Time Series is research to find out the stability of an uncertain and inconsistent state (Sugiyono, 2009).

The population and sample of companies that were the population in this study were all companies that had gone public that had been listed in the LQ 45 active share group based on the Indonesia Stock Exchange classification from 2013 to 2017. The selected sample was companies listed in LQ 45 during the 2013 to 2017 research period. To determine the sample used purposive sampling technique with the following criteria:

1. Stocks are stocks that fall under the criteria of Active shares based on companies listed in the calculation of LQ 45 active Index in January 2013 s.d. December 2017.

2. The company was always included in the LQ 45 list during the research period which was January 2013 s.d. December 2017.

3. Have completeness of information in accordance with the 5 variables applied.

From a population of 45 companies that were in and out of the list of LQ 45 companies, then obtained the number of samples that did not meet the criteria as many as 32 companies and the number of samples that met the criteria was 13 companies as research samples during the research period 2013 - 2017. The sample was obtained from the Indonesia Stock Exchange Statistic Report in 2019 published by IDX. The selection of this sample is based on the consideration that the elements in the financial statements are relatively comparable.

\section{RESULTS AND DISCUSSIONS}

\section{Regression Analysis of Panel Data}

Regression analysis in panel data can be done with three models including Common Effect, Fixed Effect and Random Effect, so that it can be known which method is best to use in estimating factors that affect Stock Return (Y).

\section{a) Common Effect Model}

Common effect model is a simple model that combines all time series data with cross section,then done 
estimation model using OLS (Ordinary Least Square). This model assumes that the condition of an object and one time to another is the same.

Table 1. Common Effect Estimates

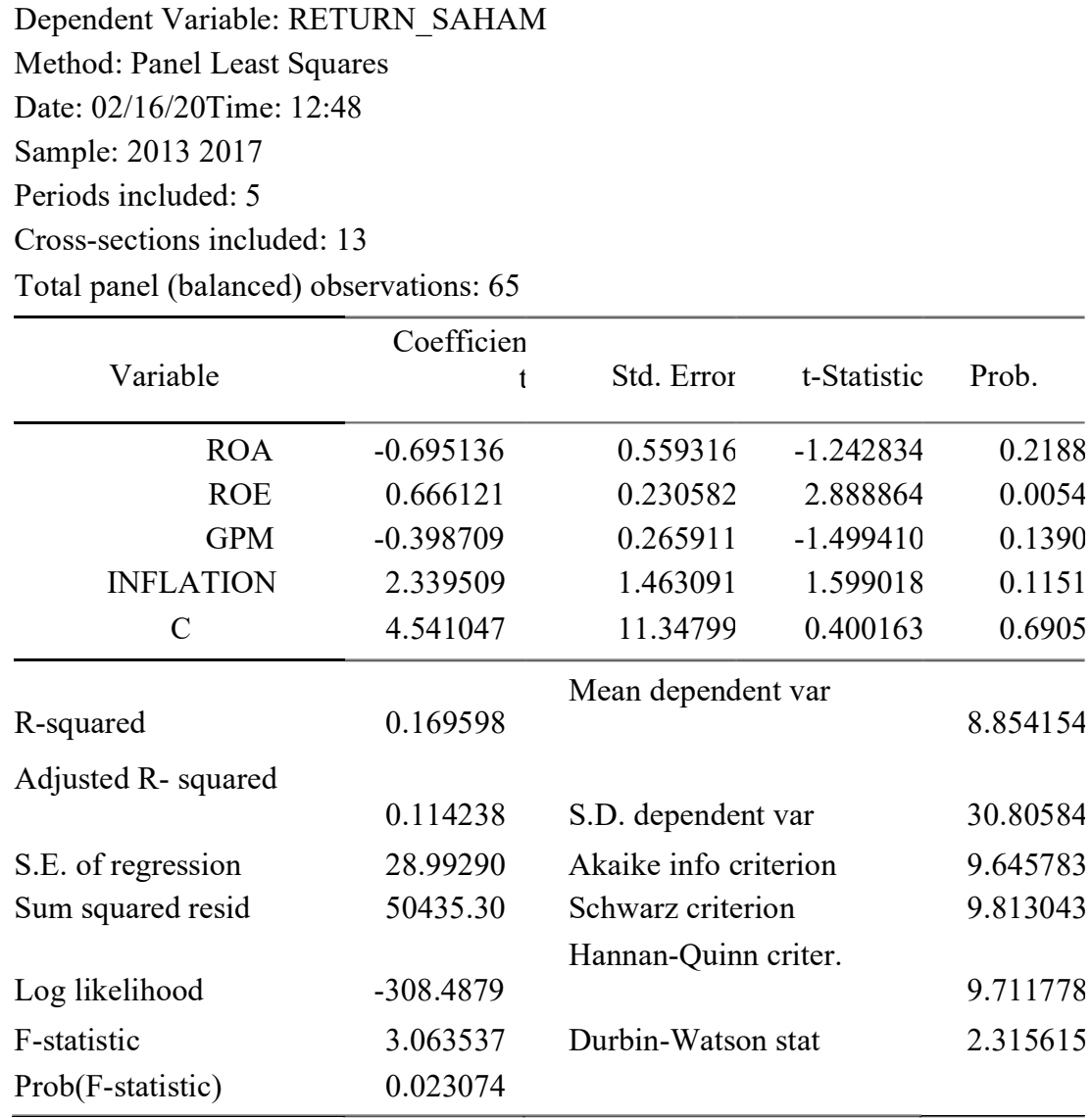

Source: Data processed with Eviews 9

Based on Table 1 multiple linear regression models for multiple models

Common effect:

$$
\mathrm{Y}=-0.695136 * \mathrm{X}_{1}+0.666121 * \mathrm{X}_{2}+(-0.398709) * \mathrm{X}_{3}+2.339509 * \mathrm{X} 4+4.541047+\mathrm{e}
$$

The regression equation above shows that the constant is 4.541047. Regression coefficients for ROA (X1)of 0.695136, ROE (X2)of 0.666121, GPM (X3)of -0.398709, and Inflation (X4)of 2.339509. Adjusted $R$-squared value $\left(\mathrm{R}^{2}\right)$ of 0.114238 .

\section{b) Fixed Effect Model}

One of the difficulties of the panel's data procedure is that every consistent interception and slop is difficult to meet. To overcome this, what is done in the panel data is to include dummy variables (dummy variables). The approach by including the doll variable is commonly called the fixed effect model or least square dummy variable (LSDV). 
Table 2. Fixed Effect Estimated Results

Dependent Variable: RETURN_SAHAM

Method: EGLS panel (Cross-section weights)

Date: 02/16/20 Time: 12:52

Sample: 20132017

Periods included: 5

Cross-sections included: 13

Total panel (balanced) observations: 65

Linear estimation after one-step weighting matrix

White cross-section standard errors \& covariance (d.f. corrected)

WARNING: estimated coefficient covariance matrix is of reduced rank

\begin{tabular}{|c|c|c|c|c|}
\hline Variable & Coefficient & Std. Error & $\mathrm{t}$-Statistic & Prob. \\
\hline ROA & 0.114248 & 0.098569 & 1.159069 & 0.2522 \\
\hline ROE & 1.032152 & 0.224285 & 4.601958 & 0.0000 \\
\hline GPM & 4.933750 & 0.174911 & 28.20725 & 0.0000 \\
\hline INFLATION & 0.927387 & 0.370286 & 2.504512 & 0.0157 \\
\hline $\mathrm{C}$ & -191.2023 & 5.484634 & -34.86145 & 0.0000 \\
\hline & \multicolumn{4}{|c|}{ Effects Specification } \\
\hline \multicolumn{5}{|c|}{ Cross-section fixed (dummy variables) } \\
\hline & \multicolumn{4}{|c|}{ Weighted Statistics } \\
\hline R-squared & 0.936578 & \multicolumn{2}{|c|}{ Mean dependent var } & 20.19702 \\
\hline \multicolumn{5}{|l|}{ Adjusted R-squared } \\
\hline S.E. of regression & 18.15536 & \multicolumn{2}{|c|}{ Sum squared resid } & 15821.63 \\
\hline F-statistic & 44.30216 & \multicolumn{2}{|c|}{ Durbin-Watson stat } & 2.071782 \\
\hline \multirow[t]{2}{*}{ Prob(F-statistic) } & 0.000000 & & & \\
\hline & \multicolumn{4}{|c|}{ Unweighted Statistics } \\
\hline R-squared & 0.734001 & \multicolumn{2}{|c|}{ Mean dependent var } & 8.854154 \\
\hline Sum squared resid & 16155.74 & \multicolumn{2}{|c|}{ Durbin-Watson stat } & 2.061486 \\
\hline
\end{tabular}

Source: Data processed with Eviews 9

Based on the Tabel 2 multiple linear regression model for the fixed effect model:

$\mathrm{Y}=0.114248 * \mathrm{X} 1+1.032152 * \mathrm{X}_{2}+4.933750 * \mathrm{X}_{3}+0.927387 * \mathrm{X} 4+(-191.2023)+\mathrm{e}$ The regression equation above shows that the constant is -191.2023 . Regression coefficients for ROA (X1)amounted to 0.114248, ROE (X2)amounted to 1.032152, GPM (X3)of4.933750, and Inflation (X4)of 0.927387. Adjusted R-squared value ${ }^{(\mathrm{R} 2)}$ of 0.915437. 


\section{c) Random Effect Model}

Random effect model (REM) is used to overcome the weaknesses of fixed effect models that use dummy variables. The use of variable dummy will reduce the degree of freedom which will ultimately reduce the efficiency of the estimated parameters.

Table 3. Random Effect Estimation Results

Dependent Variable: RETURN_SAHAM

Method: EGLS panel (Cross-section random effects)

Date: 02/16/20 Time: 12:54

Sample: 20132017

Periods included: 5

Cross-sections included: 13

Total panel (balanced) observations: 65

Swamy and Arora estimator of component variances

White cross-section standard errors \& covariance (no d.f. correction)

WARNING: estimated coefficient covariance matrix is of reduced rank

\begin{tabular}{|c|c|c|c|c|}
\hline Variable & Coefficient & Std. Error & t-Statistic & Prob. \\
\hline $\mathrm{ROA}$ & -0.782477 & 0.192856 & -4.057311 & 0.0001 \\
\hline ROE & 0.770249 & 0.195300 & 3.943933 & 0.0002 \\
\hline GPM & -0.355557 & 0.201704 & -1.762768 & 0.0830 \\
\hline INFLATION & 2.340367 & 1.526993 & 1.532664 & 0.1306 \\
\hline \multirow[t]{3}{*}{$\mathrm{C}$} & 1.883364 & 11.08882 & 0.169844 & 0.8657 \\
\hline & \multicolumn{4}{|c|}{ Effects Specification } \\
\hline & & & S.D. & Rho \\
\hline Cross-section random & & & 6.289847 & 0.1055 \\
\hline \multirow[t]{2}{*}{ Idiosyncratic random } & & & 18.31113 & 0.8945 \\
\hline & \multicolumn{4}{|c|}{ Weighted Statistics } \\
\hline R-squared & 0.176970 & Mean dependent var & & 7.021897 \\
\hline Adjusted R-squared & 0.122102 & S.D. dependent var & & 29.99962 \\
\hline S.E. of regression & 28.10851 & Sum squared resid & & 47405.30 \\
\hline F-statistic & 3.225345 & Durbin-Watson stat & & 2.357745 \\
\hline \multirow[t]{2}{*}{ Prob(F-statistic) } & 0.018299 & & & \\
\hline & \multicolumn{4}{|c|}{ Unweighted Statistics } \\
\hline R-squared & 0.161692 & Mean dependent var & & 8.854154 \\
\hline Sum squared resid & 50915.44 & Durbin-Watson stat & & 2.195200 \\
\hline
\end{tabular}

Source: Data processed with Eviews 9

Based on the Table 3 multiple linear regression model for the random effect model:

$$
\mathrm{Y}=-0.782477 * \mathrm{X} 1+0.770249 * \mathrm{X}_{2}+(-0.355557) * \mathrm{X}_{3}+2.340367 * \mathrm{X} 4+1.883364+\mathrm{e}
$$

The regression equation above shows that the constant is 1.883364. Regression coefficients for ROA (X1)of 0.782477, ROE (X2)of 0.770249, GPM (X3)of -0.355557, and Inflation (X4)of 2.340367. Adjusted R-squared value $^{(\mathrm{R} 2)}$ of 0.122102 . 


\section{Selection of Panel Data Regression Model}

\section{a) Chow Test}

This test is done comparing or choosing which model is most appropriate between the Common Effect method and fixed effect. The results of the F-Test using the Eviews 9 Program are as follows.

Table 4. Chow Test Results

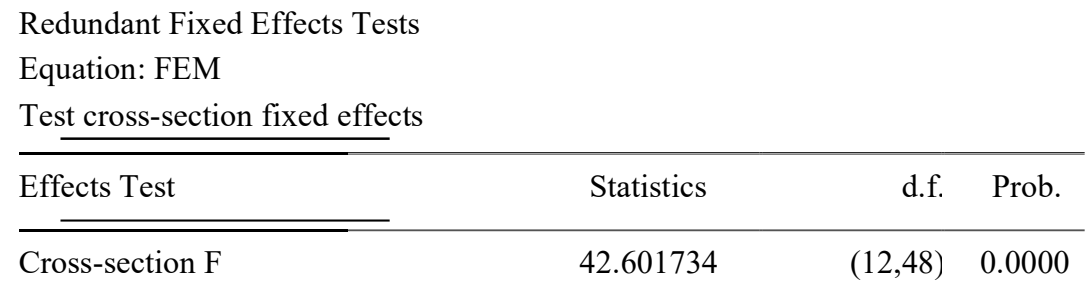

Source: Data processed with Eviews 9

Based on Table 4 a significant cross-section $F$ level of 0.0000 . The level of significance is smaller than 0.05 which means hypothesis $\mathrm{H} 0$ is rejected so it can be concluded that the Fixed Effect method is a more suitable method of analysis to use.

\section{b) Lagrange Multiplier (LM) Test}

To find out if the random effect model is better than the common effect method, the Lagrange Multiplier (LM) test is used. Lm tests are performed by looking for residual values with the help of the Eviews 9 application.

Table 5. Lagrange Multiplier Test Results

Lagrange Multiplier Tests for Random Effects

Null hypotheses: No effects

Alternative hypotheses: Two-sided (Breusch-Pagan) and one-sided

(all others) alternatives

\begin{tabular}{|c|c|c|c|}
\hline & \multicolumn{3}{|c|}{ Test Hypothesis } \\
\hline & $\begin{array}{l}\text { Cross- } \\
\text { section }\end{array}$ & Time & Both \\
\hline \multirow[t]{2}{*}{ Breusch-Pagan } & 0.626456 & 0.282797 & 0.909253 \\
\hline & $(0.4287)$ & $(0.5949)$ & $(0.3403)$ \\
\hline \multirow[t]{2}{*}{ Honda } & -0.791490 & 0.531787 & -0.183638 \\
\hline & -- & $(0.2974)$ & -- \\
\hline \multirow[t]{2}{*}{ King-Wu } & -0.791490 & 0.531787 & 0.064796 \\
\hline & -- & $(0.2974)$ & $(0.4742)$ \\
\hline \multicolumn{4}{|l|}{ Standardized } \\
\hline \multirow[t]{2}{*}{ Honda } & -0.309034 & 1.387284 & -3.099084 \\
\hline & -- & $(0.0827)$ & \\
\hline
\end{tabular}




$\begin{array}{lccc}\text { Standardized King- Wu } & & & \\ & -0.309034 & 1.387284 & -2.488882 \\ \text { Gourierioux, et al.* } & -- & (0.0827) & -- \\ & -- & -- & 0.282797 \\ & & & (>=0.10)\end{array}$

*Mixed chi-square asymptotic critical values:

\begin{tabular}{rr}
$1 \%$ & 7.289 \\
$5 \%$ & 4.321 \\
$10 \%$ & 2.952 \\
\hline
\end{tabular}

Source: Data processed with Eviews 9

Based on Table 5 breusch-pagan significant level of 0.4287 . The level of significance is greater than 0.05 which means hypothesis $\mathrm{H} 0$ is rejected so it can be concluded that the Random Effect method is a more suitable method of analysis to use.

\section{c) Haussman Test}

Hausman test aims to compare between fixed effect method and random effect method. The result of testing using this test is to find out which method should be chosen. Here are the results of the Hausman test:

Table 6. Haussman Test Results

Correlated Random Effects - Hausman Test

Equation: REM

Test cross-section random effects

\begin{tabular}{lcrrr}
\hline Test Summary & $\begin{array}{c}\text { Chi-Sq. } \\
\text { Statistics }\end{array}$ & $\begin{array}{r}\text { Chi-Sq. } \\
\text { d.f. }\end{array}$ & Prob. \\
\hline Cross-section random & 0.000000 & 4 & 1.0000 \\
\hline
\end{tabular}

Source: Data processed with Eviews 9

Based on Table 6 the random Cross-Setion significance level is 0.0000 . The significance level is less than 0.05 which means Hypothesis $\mathrm{H} 0$ is rejected. This shows the Fixed Effect model received.

\section{d) Model Conclusions}

Table 7. Panel Data Regression Selection Results

\begin{tabular}{llc}
\hline \multicolumn{1}{c}{ Selection Test Method } & Model Results Testing & Model used \\
\hline Chow Test, selection: & Common Effect vs Fixed Effect, & Fixed Effect \\
$\mathrm{H} 0=$ CEM H $1=$ FEM & F Prob $=0.0000<\alpha 0.05$ & Model (FEM) \\
H0 if Test F Prob. $>\alpha 0.05$ H1 if & & \\
Test F Prob. $<\alpha 0.05$ & & \\
& & \\
\hline
\end{tabular}




\author{
Lagrange Multiplier (LM- \\ Test), selection: \\ $\mathrm{H} 0=\mathrm{CEM} \mathrm{H} 1=\mathrm{REM}$ \\ $\mathrm{H} 0$ if cross-section $>\alpha 0.05$ \\ $\mathrm{H} 1$ if cross-section $<\alpha 0.05$
}

Common Effect vs Random Effect,

Cross-section $=0.0000>\alpha 0.05$

Common Effect

Model (CEM)

\section{HaussmanTest, selection \\ : \\ $\mathrm{H}_{0}=\mathrm{R} E M \mathrm{H} 1=\mathrm{FEM}$ \\ $\mathrm{H}_{0}$ if the Haussman Test prob. \\ $>\alpha 0,05$ \\ $\mathrm{H} 1$ if the Hausman Test prob. \\ $<\alpha 0,05$}

Fixed Effect vs RandomEffect, where Prob.

$0.0000>\alpha 0.05$

Random Effect

Source: Data processed by researchers

The results of paired tests using chow tests, LM tests, and Haussman tests against all three panel data regression methods, it can be concluded that we have not been able to decide which model is the most appropriate of the panel data regression methods used because all three models turned out to be dominant. Further to estimate and analyze by looking at $\mathrm{R}$ squared $\left(\mathrm{R}^{2)}\right.$

So it can be concluded that the fixed effect model is better than the other two panel data regression models, namely the common effect and random effect models to estimate the model because it has a coefficient of determination value $\mathrm{R}^{2}$ and the highest coefficient of determination adjusted $\mathrm{R}^{2}$ is the fixed effect model.

\section{Hypothesis Test}

\section{a) Partial Significance Test (Test t)}

The $t$ test is used to measure how far the influence of one individually free variable in describing a dependent variable.

Table 8. PartialLy Significant Test

Dependent Variable: RETURN_SAHAM

Method: EGLS panel (Cross-section weights)

Date: 02/16/20 Time: 12:52

Sample: 20132017

Periods included: 5

Cross-sections included: 13

Total panel (balanced) observations: 65

Linear estimation after one-step weighting matrix

White cross-section standard errors \& covariance (d.f. corrected)

WARNING: estimated coefficient covariance matrix is of reduced rank

\begin{tabular}{rrrrr}
\hline Variable & \multicolumn{1}{l}{ Coefficient } & \multicolumn{1}{l}{ Std. Error } & \multicolumn{1}{l}{ t-Statistic } & \multicolumn{1}{l}{ Prob. } \\
\cline { 1 - 1 } ROA & 0.114248 & 0.098569 & 1.159069 & 0.2522 \\
ROE & 1.032152 & 0.224285 & 4.601958 & 0.0000
\end{tabular}




\begin{tabular}{rrrrr} 
GPM & 4.933750 & 0.174911 & 28.20725 & 0.0000 \\
INFLATION & 0.927387 & 0.370286 & 2.504512 & 0.0157 \\
C & -191.2023 & 5.484634 & -34.86145 & 0.0000 \\
\hline
\end{tabular}

Effects Specification

Cross-section fixed (dummy variables)

Weighted Statistics

\begin{tabular}{llll}
\hline R-squared & 0.936578 & Mean dependent var & 20.19702 \\
Adjusted R-squared & 0.915437 & S.D. dependent var & 69.53440 \\
& 18.15536 & Sum squared resid & 15821.63 \\
S.E. of regression & 44.30216 & Durbin-Watson stat & 2.071782 \\
F-statistic & 0.000000 & \\
Prob(F-statistic) & & \\
\hline
\end{tabular}

\begin{tabular}{llll}
\hline & \multicolumn{3}{c}{ Unweighted Statistics } \\
\hline R-squared & 0.734001 & Mean dependent var & 8.854154 \\
Sum squared resid & 16155.74 & Durbin-Watson stat & 2.061486 \\
\hline
\end{tabular}

Source: Data processed with Eviews 9

1) ROA hypothesis (X1)to stock return ( $\mathrm{Y})$

The significance test performed on the free variable can be seen from the p-value. From the regression results obtained that with a significance rate of $95 \%(\alpha=5 \%)$ with table t 2.00030 and $\mathrm{df}=60$, the ROA variable has astatistical t of 1.159069 and a p-value of 0.2522 . Since the value p-value $>0.05$, Ho is accepted. Thus it was concluded that the ROA variable had no effect and was not significant to the Stock Return. H1 is not proven.

2) Roe hypothesis(X2)to return shares $(\mathrm{Y})$

The significance test performed on the free variable can be seen from the p-value. From the regression results obtained that with a significance rate of $95 \%(\alpha=5 \%)$ with table $\mathrm{t} 2.00030$ and $\mathrm{df}=60$, the ROE variable has astatistical t of 4.601958 and a p-value of 0.0000 . Because the p-value $<0.05$, Ho was rejected.

Thus it was concluded that the ROA variable had a positive and significant effect on stock returns. Thus $\mathrm{H} 2$ is proven.

3) GPM Hypothesis(X3)to Stock Return (Y)

The significance test performed on the free variable can be seen from the $p$-value. From the regression results obtained that with a significance rate of $95 \%(\alpha=5 \%)$ with table t 2.00030 and $\mathrm{df}=60$, the GPM variable has astatistical $\mathrm{t}$ of 28.20725 and a $p$-value of 0.0000 . Because the p-value $<0.05$, Ho was rejected. Thus it was concluded that the GPM variable had a positive and significant effect on stock returns. Thus H3 is proven.

4) Inflation Hypothesis (X4)to Stock Return (Y)

The significance test performed on the free variable can be seen from the $p$-value. From the regression results obtained that with a significance rate of $95 \%(\alpha=5 \%)$ with table $t 2.00030$ and $\mathrm{df}=60$, the GPM variable has astatistical $\mathrm{t}$ of 2.504512 and a $p$-value of 0.0157 . Because the $\mathrm{p}$-value $<0.05$, Ho was rejected. Thus it was concluded that inflation variables have a positive and significant effect on stock returns. Thus $\mathrm{H} 4$ is proven.

\section{b) Simultaneous Significance Test (Test F)}


Table 9. Significant Test F

\begin{tabular}{lclc}
\hline & \multicolumn{3}{c}{ Weighted Statistics } \\
\hline R-squared & 0.936578 & Mean dependent var & 20.19702 \\
Adjusted R- squared & 0.915437 & S.D. dependent var & 69.53440 \\
& 18.15536 & Sum squared resid & 15821.63 \\
S.E. of regression & 44.30216 & Durbin-Watson stat & 2.071782 \\
F-statistic & 0.000000 & & \\
Prob(F-statistic) & & & \\
\hline
\end{tabular}

Source: Data processed with Eviews 9

The statistical test $\mathrm{F}$ basically shows whether all the free variables included in the model have a collective influence on dependent variables to make accepted or rejected hypothesis decisions by comparing the error rate of 0.05 (Ghozali, 2016). In the Eviews 9 application, the F test is indicated by the probability value of F-statistics. Based on the results of the above test, F-statistics have a value of 44.30216 or greater than Ftable of 2.53 with $\mathrm{df}=60$. While the probability value of F-statistics is 0.000000 or less than 0.05 , so Ho is rejected and Ha is accepted. This means that the variables ROA, ROE, GPM and Inflation together have a significant effect on Stock Return (Y) in consumer goods industry companies listed on the Indonesia Stock Exchange period 2013 to 2017 . Thus H5 is proven.

\section{c) Coefficient of Determination}

The Coefficient of Determination is used to measure how far the model's ability to explain independent variables $(\mathrm{X})$ to dependent variables $(\mathrm{Y})$. In the Eviews 9 application, the coefficient of determination is indicated by Adjusted $R$-Square, where in this study Adjusted $R$-Square has a value of 0.915437 which can be seen in the table above (Fixed EffectEstimation Results). This means that simultaneously the independent variables in this study contributed to dependent variables by $91.54 \%$, while the remaining $8.46 \%$ were explained by other variables outside the study or not included in this research model.

\section{Discussion}

The results of estimates with fixed effect models, to test the effect of independent variables (ROA, ROE, GPM, and INFLATION) on dependent variables (Return Shares) can be compiled as follows: $\mathrm{Y}=0.114248 * \mathrm{X} 1+1.032152 * \mathrm{X}_{2}+4.933750 * \mathrm{X} 3+0.927387 * \mathrm{X} 4+(-191.2023)$.

This can be explained in the five hypotheses below:

\section{a. The First Hypothesis (H1)}

Based on the results of multiple linear regressions and test results, it can be known or found that the coefficient of the ROA variable has no effect on the Return of Shares because based on the test $t$ the value is 0.114248 . In addition, the probability significance value of $0.2522>0.05$ with a statistical value of $1.159069<$ ttable of 2.00030 which means ROA has no significant effect on Stock Return. The results of this study prove that ROA has no effect and is not significant to stock returns. This is because the company's management is unable to use total assets properly (current assets and fixed assets) and ultimately cannot increase the Return of company shares. This is less of an attraction for potential investors to plant shares in the company, because the return of shares decreases.

This researcher is in line with Wahyuni's (2013) research which states that there is no roa effect on stock returns as it has been explained that this ratio is used to measure management's ability to obtain net profits and the use of assets.

\section{b. Second Hypothesis (H2)}

Based on the results of multiple linear regression and the results of the $t$ test, it can be known or found that the coefficient of roe variable has a positive effect because based on the test the value is 1.032152 . In addition, the probability significance value of $0.0000<0.05$ with astatistical t of $4.601958>$ ttable of 2.00030 which means ROE has a significant effect on stock return. The results of this study prove that ROE has a positive and significant effect on stock returns. This is because the company's management can use its capital (own capital or foreign capital) to operate the company properly or in other words appropriately, so that this can increase the return of 
the company's shares and become an attraction for investors to invest in the company. This research is in line with Novella's research (2012) stating that there is a positive and significant influence between ROE on Stock Return.

\section{c. Third Hypothesis (H3)}

Based on the results of multiple linear regressions and $t$ test results, it can be known or found that the coefficient of GPM variables has a positive effect because based on the test the value is 4.933750 . In addition, the probability significance value of $0.0000<0.05$ with astatistical t of $28.20725>$ ttable of 2.00030 which means GPM has a significant influence on Stock Return. The results of this study prove that GPM has a positive and significant effect on Stock Return. This is because the company's management can generate gross profit (total sales minus operating costs) with high returns to be re-used in the company's operational financing, so this can increase the return of the company's shares and become an attraction for investors to invest in the company. This research is in line with the research Engrossed (2011), GPM has a positive and significant effect on Stock Return.

\section{d. Fourth Hypothesis (H4)}

Based on the results of multiple linear regression and the results of the $t$ test, it can be known or found that the coefficient of the INFLATION variable has a positive effect because based on the test the value is 0.927387 . In addition, the probability significance value of $0.0157<0.05$ with astatistical $t$ of $2.504512>$ ttable of 2.00030 which means inflation has a significant effect on stock return. The results of this study prove that Inflation has a positive and significant effect on stock returns. This is because the company's management can produce price increases that are influenced by increased demand (demand) from consumers for consumer goods companies to continue to be produced, so this can increase the return of the company's shares and become an attraction for investors to invest in the company. This research is in line with dwita and rose research (2012) which states that inflation has an effect and significant on stock returns.

\section{e. Fifth Hypothesis (H5)}

It can be seen that the statistical $F$ shows a value of 44.30216 with a significance level below $5 \%$ or 0.05 while the Ftable shows a value of 2.53 which means that thestatistical $F>$ Ftable. In addition, the significance value of $0.000000<0.05$ which means, ROA, ROE, GPM, and Inflation simultaneously have a positive and significant influence on stock returns. And based on the results of the model conclusion that the Fixed Effect Model is better than the other two panel data regression models, namely the Common Effect Model and the Random Effect Model. Where it can be shown that the highest Adjusted R-Square Fixed Effect Model value is 0.915437 , meaning that the independent variable $(\mathrm{X})$ in this study can contribute to the dependent variable $(\mathrm{Y})$ of $91.54 \%$, while the remaining $8.46 \%$ is explained by other variables outside the study or not included in the study model.

\section{CONCLUSION}

1. Partially ROA causes changes to stock returns which can be concluded that there is no influence and no significance between the two, meaning that if the ROA falls then the Stock Return will fall which is vice versa if the ROA rises and rerutn shares will also increase.

2. Partially ROE does not cause changes in Stock Return which can be concluded that there is a positive influence and significance between the two, meaning that if roe rises then the stock return will rise otherwise if roe falls then stock return will also decrease.

3. Partially GPM does not cause changes in Stock Return which can be concluded that there is a positive influence and significance between the two, meaning that if GPM rises then the Stock Return will rise which is vice if roe falls then stock return will also decrease.

4. Partially Inflation does not cause changes in Stock Return which can be concluded that there is a positive influence and significance between the two, meaning that if roe rises then the stock return will rise which is vice versa if roe falls then the stock return will also decrease.

5. Simultaneously ROA, ROE, GPM, Inflation does not cause changes in Stock Return which can be concluded that there is a positive influence and significance on the four independent variables, it is explained that if $91.54 \%$ is influenced by the four independent variables, and the remaining $8.46 \%$ is influenced by other variables outside the study. 


\section{Suggestion}

1. Companies should consider the influence of ROA, ROE, GPM Inflation and pay attention to other factors such as NPM as a basic tool of financial statement information in increasing Stock Returns, because prospective investors will be more interested in investing in companies with high Stock Returns.

2. For potential investors, in assessing a company, prospective investors should be careful in choosing or determining which companies to invest in by paying attention to factors that affect stock returns, so that prospective investors can portfolio wisely.

3. For further researchers, it can change the observation period longer than five years and use different populations and wider scope so that the results of the study are better at reflecting the actual circumstances related to the influence of factors on Stock Return. Researchers can add macroeconomic factors or in addition to financial ratios such as interest rates, the rupiah exchange rate against the dollar as affecting stock returns.

\section{BIBLIOGRAPHY}

Ang, Robert. (1997). Indonesian Capital Market Smart Book(The Intelegent Guide to Indonesian Capital Market). Mediasoft Indonesia.

Fun, N. F. (2011). Market Reactions to Macro Variables And Profitability: Company Review on Indonesia Stock Exchange Categorized devensife and Cyclical Industry. EQUITIES (Journal of Economics and Finance), 15(2), 269-287.

Baramuli, Dedy N.(2012). Effect of Inflation, Exchange Rate, Interest Rate and Gross Gross Gross On Stock Returns. Journal of Accounting Research Going Concern FE UNTRAT.

Dini, M. Nurhayati. 2015. Effect of Financial Performance on Return of Shares on Manufacturing Companies Listed on the Indonesia Stock Exchange. Journal of Accountants, 1(1).

Dwita, V., \& Rahmidani, R. (2012). The effect of inflation, interest rates and exchange rates on the return of shares of the restaurant hotel and tourism sectors. Journal of Business Management Studies, 1(1).

Farkhan and Ika. (2013). Effect of Financial Ratio to Return of Shares of Manufacturing Companies on the Indonesia Stock Exchange (Case Study on Food and Beverages Sector Manufacturing Companies). Value Added Journal,9 (1). Unimus.

Gerald Ey Egam, Ventje Ilat, Sonny Pangarepan. (2017). The Effect of Return On Asset, Return On Equity, Net Profit Margin and Earning Per Share Toward Stock Prices Companies Contained in the LQ45 Index in Indonesia Stock Exchange Period 2013-2015, Journal of Economic, Management, Business and Accounting Research, 5 (10).

Ghozali, Imam and Irwansyah. (2002). Analysis of the Effect of The Company's Financial Performance with EVA, MVA and ROA Measuring Instruments on Stock Return on Manufacturing Companies in JJs. Journal of Accounting-Business and Management Research, 9 (1), 18-33

Giovanni, Budialim. (2013). The Effect of Financial Performance and Risk on the Stock Return Company of Goods Consumer Sector in Indonesia Stock Exchange Period 2007-2011. Journal of Scientific Students in SurabayaUniversity, 2 (1).

Gujarati, Damodar \& Porter Dawn C.(2015). The basics of econometrics. Jakarta. Institution Publisher Erlangga.

Hermi and Kurniawan, Ari. (2011). Effect of Financial Performance On Stock Return on Manufacturing Companies Listed on IDX Period 2008-2010. Journal of Accounting And Public Finance Taxation Information, 6(2), July.

Horne, James C.V and Wachoviz Jr., John M.(1998). Fundamental of Financial Management, 8th ed. New Jersey, Prentice Hall International.

Jogiyanto. (2003). Portfolio Theory and Investment Analysis, Edition 3. BPFE. Yogyakarta.

Jogiyanto Hartono and Chendrawati. (1999). ROA and EVA: A Comaprative EmpiricalStudy. Gajah Mada International Journal of Bussines 1 (May): 45-54.

Kahana, Tri. (2012). The Effect of Liquidity Ratio, Laverage, Activity and Profitability to Return Shares are listed in IDX Manufacturing companies for the period 2008-2011. Journal of Indonesian Business Management, 2 (3).

Cashmere. (2013). Introduction to Financial Management. Jakarta. Kharisma Putra Utama Publishing Institution. Kuncoro, Mudrjad. (2009). Indonesia's economy. Yogyakarta. UPP Issuing Institution STIM YKPN

Mamduh M. Hanafi, Abdul Halim. (2007). Analysis of Financial Statements, Third Edition. UPP STIM YKPN, Yogyakarta

Munawir. (2013). Analysis of financial statements. Yogyakarta. Liberty Publishing Society. 
Nanda, D. S. R. (2017). The effect of operating cash flow and net income on the return of shares in mining companies listed on the Indonesia Stock Exchange (IDX) tahun@ 011-2013, (Doctoraldissertation,IAIN Padangsidimpuan).

Novelia, Lauren. (2012). Influence of ROA, EPS, EVA, NPM and ROE on Return shares in Manufacturing Companies listed on IDX Period 2007-2010, Jurnal Manajemen Bisnis Indonesia, 1 (2).

Nuryana, I. (2013). The Effect of Financial Ratio to Return of LQ 45 Company Shares on the Jakarta Stock Exchange. Journal of Actual Accounting, 2(2), 57-66.

Prihantini, R. (2009). Analysis of the Effect of Inflation, Exchange Rate, ROA, DER and CR on Stock Returns (Case Study of Real Estate and Property Industry Shares Listed on the Indonesia Stock Exchange Period 2003-2006), Doctoral dissertation, Diponegoro University Post-GraduateProgram.

Riduwan. (2010). The basics of statistics. Bandung. Alphabet publisher.

Riyanto, Bambang. (2008). The basics of corporate spending. Yogyakarta. Bpfe Yogyakarta Issuing Agency.

Rosa, M., \& Mulyani, E. (2013). Effect of Profitability, OCF, and EVA on the Return of Shares of Manufacturing Companies Listed on IDX. Accounting Research Vehicle, 1(2), 219-242.

Sakaran, Uma. (2006). Business Research Methodology translation Kwan Men Yon Book Two EditionFour. Jakarta. Publisher Salemba Four.

Sambelay, J. J., Van Rate, P., \& Baramuli, D. N. (2017). Analysis of the effect of profitability on stock prices on companies listed in LQ45 for the period 2012-2016. Journal of EMBA: Journal of Economic Research, Management, Business and Accounting, 5(2).

Santoso, Budi Purbayu, Ashari. (2005). Statistical Analysis with Microsoft Excel and SPSS. Yogyakarta. Publisher Andy Offset.

Sparta. (2000). Analysis of the Influence of ROA, DER, and DPR on PBV on Bank Financial Institutions in the J.J. Period 1992-1996. Fe Untar Accounting Journal.

Sudiyanto, Bambang and Suharmanto, Toto. (2011). Conventional Financial Performance, Economi Value Added and Stock Return. Journal of Management Dynamics, 2 (2), 153-161

Sugiyono. (2007). Business Research Methods. Bandung. Publisher of ALFABETA CV.

Suriani, Ginting. (2012). Analysis of the Effect of Cash Flow Growth and Profitability on Stock Return at LQ45 Companies on the Indonesia Stock Exchange. Journal of Microeconomic Entrepreneur, 2 (1).

Susilowati, Y., \& Turyanto, T. (2011). Signal reaction to profitability ratio and solvency to return ratio of company shares. Financial and banking dynamics, 3(1), 17-37.

Verawaty, V., Jaya, A. K., \& Mendala, T. (2015). Effect of Financial Performance on Stock Return on Mining Companies Listed on Indonesia Stock Exchange. Acquisition: Accounting Journal, 11(2).

Widarjono, Agus. (2013). Econometrics: Introduction and application, Ekonosia, Jakarta.

Winarno, Wing of Revelation. (2015). Analysis of Econometrics and Statistics with Eviews Third Edition. Yogyakarta. UPP Issuing Institution STIM YKPN. 